\title{
Mariusz Kudełko
}

AGH Akademia Górniczo-Hutnicza

e-mail: mkudelko@zarz.agh.edu.pl

\section{ENERGETYCZNY DLA POLSKI - DWIE ODMIENNE PERSPEKTYWY*}

\section{ENERGY MIX FOR POLAND - TWO DIFFERENT PERSPECTIVES}

DOI: 10.15611/pn.2018.509.18

JEL Classification: P18, Q47, Q57

Streszczenie: Celem artykułu jest wskazanie dwóch odmiennych wizji rozwoju krajowego sektora energetycznego. Pierwsza z nich to model oparty na istniejących zasobach węgla kamiennego i brunatnego, uzupełniony technologiami alternatywnymi (wiatr, biomasa, energia jądrowa). Druga to model alternatywny, w którym uwzględniono ekonomiczne skutki emisji zanieczyszczeń gazowych. Jako narzędzie prognostyczne wykorzystany został matematyczny model optymalizacyjny. Obliczenia przeprowadzono dla dwóch scenariuszy: „bazowego” i „efektywnego”. W obliczany jest optymalny „mix produkcyjny” krajowego sektora energetycznego, w drugim - optymalna struktura produkcji energii dla pełnej internalizacji kosztów zewnętrznych. Wyniki obliczeń wskazują, że scenariusz „efektywnościowy” jest „droższy” od „bazowego" w sensie ponoszonych kosztów produkcji (prywatnych) - 638 mld zł w stosunku do $623 \mathrm{mld}$ zł, jednak generuje o wiele niższe koszty zewnętrzne (275 zamiast $521 \mathrm{mld}$ zł).

Słowa kluczowe: sektor energetyczny, modelowanie matematyczne, koszty zewnętrzne.

Summary: The purpose of this article is to indicate two different visions for the development of the domestic energy sector. The first one is a model based on existing hard and brown coal, supplemented by alternative technologies (wind, biomass, nuclear energy). The second is an alternative model, where the economic effects of emissions pollution are taken into account. As a forecasting tool, a mathematical optimization model was used. The optimization calculations were done for two mian scenarios: „base” and „effective”. In the first of these, the optimal ,production mix" of the domestic energy sector for current and future environmental regulations is calculated. The second one determines the optimal structure of energy production for full internalisation of external costs. The results of the calculations indicate that the "effective" scenario is more expensive than the ,base" in the sense of production (private) costs -638 billion PLN compared to 623 billion PLN, but it generates much lower external costs (275 instead of 521 billion PLN).

Keywords: energy sector, methematical modelling, external costs.

* Wydanie publikacji finansowane przez Akademię Górniczo-Hutniczą im. Stanisława Staszica w Krakowie (dotacja podmiotowa na utrzymanie potencjału badawczego). 


\section{Wstęp}

Według Europejskiej Agencji Środowiska w naszym kraju rocznie z powodu zanieczyszczonego powietrza umiera ok. 50 tys. ludzi [Air quality in Europe 2017, s. 57]. Tematyka ta $\mathrm{w}$ ostatnim czasie stała się przedmiotem licznych informacji medialnych w kontekście smogu występującego w polskich miastach, głównie zlokalizowanych na południu kraju. Można także zauważyć zwiększającą się świadomość społeczeństwa co do szkodliwości tego zjawiska. Co prawda smog dotyczy przede wszystkim tzw. niskiej emisji pochodzącej z pieców węglowych czy transportu samochodowego, niemniej jednak problem zanieczyszczenia powietrza i jego wpływu na środowisko i ludzi ma szerszy kontekst w jakości paliw zużywanych do produkcji energii. Chodzi tu głównie o krajowy sektor energetyczny, którego wpływ na środowisko ma wymiar nie tylko lokalny, lecz także regionalny. $\mathrm{Z}$ tego względu tocząca się obecnie w kręgach naukowych i politycznych dyskusja o przyszłości krajowego sektora energetycznego nie jest obojętna dla zdrowia przyszłych pokoleń.

Literatura dotycząca kierunków rozwoju sektorów energetycznych jest bardzo bogata. Szczególnie warte uwagi są te opracowania, które ujmują obraz sektora w kategorii systemu wzajemnych powiązań i uwarunkowań technologiczno-ekonomiczno-środowiskowych, co wymaga zastosowania aparatu modelowego. Jednak tylko w nielicznych opracowaniach, i to głównie zagranicznych, rozwój sektora traktowany jest w szerszej perspektywie społecznej, uwzględniającej w kryterium decyzyjnym wysokość kosztów zewnętrznych powodowanych przez poszczególne technologie energetyczne. Przykładami są opracowania [Rafaj, Kypreos 2007; Zhang i in. 2007; Klaassen, Riahi 2007; Fahlén, Ahlgren 2010; Zvingilaite 2011; Georgakellos 2012; Weinzettela i in. 2012]. Krajowa literatura ujmująca to zagadnienie z tej perspektywy to rzadkość [Kudełko 2006], pozostałe liczne opracowania to badania modelowe nad optymalnym miksem energetycznym dostosowującym energetykę do wymagań środowiskowych, m.in. [Jankowski 2010; Krzemień i in. 2013; Wierzbowski i in. 2014; Model optymalnego miksu... 2015; Orzechowska i in. 2015; Ścieżki dekarbonizacji... 2018].

Celem niniejszego artykułu jest uzupełnienie tej luki i wskazanie dwóch odmiennych wizji rozwoju krajowego sektora energetycznego. Pierwsza z nich to w dużym skrócie tradycyjny model oparty na istniejących zasobach węgla kamiennego i brunatnego, uzupełniony w mniejszej lub większej części technologiami alternatywnymi (wiatr, biomasa, energia jądrowa). Są tutaj zaimplementowane najważniejsze regulacje środowiskowe wymagane przepisami unijnymi. Druga $\mathrm{z}$ nich to model alternatywny, w którym uwzględniono ekonomiczne skutki emisji zanieczyszczeń gazowych. Zamierzeniem autora jest zatem prezentacja własnych badań wskazujących na optymalny mix energetyczny z punku widzenia dwóch alternatywnych kryteriów decyzyjnych: prywatnego i społecznego. Artykuł składa się z dwóch części. W pierwszej opisano założenia metodyczne, druga prezentuje dyskusję wyników symulacji modelowych i najważniejsze wnioski. 


\section{Założenia modelowe}

W tabeli 1. przedstawiono zbiór technologii energetycznych i ich charakterystyki techniczno-ekonomiczne oraz emisyjne zaimplementowane w modelu optymalizacyjnym. Są to technologie istniejące (reprezentujące rzeczywisty potencjał wytwórczy krajowej energetyki), wraz z ich opcjami modernizacyjnymi, oraz technologie nowe, mogące je zastąpić. W analizie - na podstawie odpowiedniego kryterium decyzyjnego - technologie te konkurują z sobą, dostarczając energię elektryczną i ciepło. Konkurencja ta wymaga spełnienia wielu ograniczeń, takich jak m.in. dostępność i ceny paliw, dostępność mocy technologii, potencjał dostaw OZE. Możliwe opcje redukcji zanieczyszczeń gazowych to: poprawa jakościowa paliw węglowych, większy import energii elektrycznej, budowa instalacji redukcji emisji (zakłady odsiarczania spalin, palniki niskoemisyjne, katalityczna redukcja emisji, sekwestracja $\mathrm{CO}_{2}$ ), modernizacja istniejących czy budowa nowych technologii energetycznych, ograniczenie produkcji energii. Warto zauważyć, że technologie te różnią się nie tylko wysokością nakładów inwestycyjnych czy kosztów operacyjnych, lecz także współczynnikami emisji zanieczyszczeń, co czyni tę konkurencję o wiele bardziej interesującą i rzutuje na przedstawione w kolejnym rozdziale wyniki modelowe.

Jako narzędzie prognostyczne wykorzystany został matematyczny model optymalizacyjny, autorskie narzędzie stworzone i wykorzystywane do analiz rozwoju krajowego sektora energetycznego [Kudełko 2003; Kudełko i in. 2011]. Model jest aktualizowany, jego obecna wersja jest skalibrowana do roku 2015, a zakres obliczeń obejmuje rok 2035. Kryterium decyzyjne modelu oparte jest na maksymalizacji dobrobytu społecznego, definiowanego jako suma nadwyżek konsumentów i producentów na rynku energii, pomniejszonych o koszty zewnętrzne. W analizie wykorzystano system GAMS [Brook i in. 1992] i solver CPLEX. Dokładny zapis matematyczny modelu, opisujący funkcję celu określającą kryterium optymalizacji, równania kosztów, równania określające zależności technologiczne i bilansowe, ograniczenia mocy produkcyjnych i ochronnych oraz bilanse emisyjne, OZE i handlu uprawnieniami zbywalnymi, można znaleźć z pracy [Kudełko i in. 2013].

Obliczenia optymalizacyjne przeprowadzono dla trzech scenariuszy: „bazowego" i „efektywnego" - w dwóch wersjach. W pierwszym określany jest optymalny „mix produkcyjny” krajowego sektora energetycznego dla obowiązujących obecnie i w przyszłości regulacji środowiskowych (dotyczących m.in. limitów produkcji ze źródeł odnawialnych, limitów emisji zanieczyszczeń gazowych oraz uwarunkowań systemu handlu uprawnieniami zbywalnymi do emisji $\mathrm{CO}_{2}$ ). Można przyjąć, że w scenariuszu „bazowym” dokonywana jest częściowa internalizacja kosztów zewnętrznym poprzez narzucenie odpowiednich regulacji ekologicznych, jednak niekoniecznie optymalnych z punktu widzenia ich efektywności. 
Tabela 1. Charakterystyka technologii produkcji energii elektrycznej i ciepła

\begin{tabular}{|c|c|c|c|c|c|c|c|c|c|c|c|}
\hline Technologia & $\begin{array}{l}\text { Typ } \\
\text { paliwa } \\
\text { podst. }\end{array}$ & $\begin{array}{c}\text { Spraw- } \\
\text { ność } \\
\text { brutto } \\
{[\%]}\end{array}$ & $\begin{array}{c}\text { Nakł. inw. } \\
{[\mathrm{z} / \mathrm{kW}]}\end{array}$ & $\begin{array}{l}\text { Koszty } \\
\text { stałe - } \\
\text { elektr. } \\
\text { [zł/kW] }\end{array}$ & $\begin{array}{l}\text { Koszty } \\
\text { stałe - } \\
\text { ciepło } \\
{[\mathrm{zt} / \mathrm{kW}]}\end{array}$ & $\begin{array}{c}\text { Koszty } \\
\text { zmienne } \\
\text { - elektr. } \\
\text { [zł/GJ] }\end{array}$ & $\begin{array}{c}\text { Koszty } \\
\text { zmienne } \\
\text { - ciepło } \\
{[\mathrm{z} / \mathrm{GJ}]}\end{array}$ & $\begin{array}{l}\text { Wsp. } \\
\text { emisji } \\
\text { pył } \\
{[\mathrm{g} / \mathrm{GJ}]}\end{array}$ & $\begin{array}{c}\text { Wsp. } \\
\text { emisji } \\
\mathrm{SO}_{2} \\
{[\mathrm{~g} / \mathrm{GJ}]}\end{array}$ & $\begin{array}{l}\text { Wsp. } \\
\text { emisji } \\
\mathrm{NO}_{\mathrm{x}} \\
{[\mathrm{g} / \mathrm{GJ}]}\end{array}$ & $\begin{array}{l}\text { Wsp. } \\
\text { emisji } \\
\mathrm{CO}_{2} \\
{[\mathrm{~g} / \mathrm{GJ}]}\end{array}$ \\
\hline \multicolumn{12}{|c|}{ Elektrownie zawodowe } \\
\hline EZ_WK_I & w. kam. & 39.8 & 0 & 160 & 160 & 3,5 & 3,8 & 14,6 & 231,1 & 164,3 & 91,6 \\
\hline EZ WK I BIO & w. kam. & 38 & 0 & 160 & 160 & 3,5 & 3,8 & 14,6 & 231,1 & 164,3 & 91,6 \\
\hline EZ_WK_M_P & w. kam. & 40 & 600 & 160 & 160 & 3,5 & 3,8 & 11,7 & 185.0 & 136,5 & 84,5 \\
\hline EZ_WK_M_T & w. kam. & 40 & 1200 & 160 & 160 & 3,5 & 3,8 & 14,6 & 39,1 & 76.0 & 91,6 \\
\hline EZ_WK_M_F & w. kam. & 45 & 4100 & 160 & 160 & 3,5 & 3,8 & 14,6 & 190.0 & 164,3 & 82,5 \\
\hline EZ_WK_M_B & w. kam. & 38 & 200 & 160 & 160 & 3,5 & 3,8 & 14,6 & 190.0 & 164,3 & 82,5 \\
\hline EZ_WB I & w. brun. & 37,6 & 0 & 260 & 160 & 2,0 & 2,0 & 12,6 & 226,4 & 144,1 & 110,6 \\
\hline EZ_WB_I_BIO & w. brun. & 37 & 0 & 260 & 160 & 2,0 & 2,0 & 12,6 & 226,4 & 144,1 & 110,6 \\
\hline EZ_WB_M_P & w. brun. & 39 & 600 & 230 & 160 & 2,0 & 2,0 & 10,1 & 181,2 & 120,3 & 99,7 \\
\hline EZ_WB_M_T & w. kam. & 39 & 1200 & 230 & 160 & 2,0 & 2,0 & 12,6 & 22,6 & 50,0 & 110,6 \\
\hline EZ_WB_M_F & w. brun. & 45 & 4100 & 230 & 160 & 2,0 & 2,0 & 12,6 & 190,0 & 144,1 & 99,6 \\
\hline EZ_WB_M_B & w. brun. & 37 & 200 & 230 & 160 & 2,0 & 2,0 & 12,6 & 190,0 & 144,1 & 99,6 \\
\hline EZ_WB_M_S & w. brun. & 35 & 8000 & 230 & 160 & 2,0 & 2,0 & 12,6 & 226,4 & 144,1 & 30,0 \\
\hline EZ_WOD_I & en. wod. & 100 & 0 & 250 & 0 & 2,0 & 0,0 & 0 & 0 & 0 & 0 \\
\hline EZ WIA I & en. wiatr. & 100 & 0 & 0 & 3,5 & 0,0 & & 0 & 0 & 0 & 0 \\
\hline EZ_WK_N & w. kam. & 46 & 5900 & 160 & 160 & 3,5 & 3,8 & 14,6 & 80,0 & 87,0 & 91,6 \\
\hline EZ_WB_N & w. brun. & 46 & 7100 & 230 & 160 & 2,0 & 2,0 & 12,6 & 80,0 & 72,5 & 110,6 \\
\hline EZ PGK N & w. kam. & 47 & 8000 & 160 & 160 & 1,7 & 1,7 & 13,1 & 2,3 & 80,8 & 82,3 \\
\hline EZ_PGB_N & w. brun. & 46 & 8000 & 230 & 160 & 1,7 & 1,7 & 11,3 & 2,2 & 70,9 & 99,4 \\
\hline EZ_TG_N & gaz & 38 & 1200 & 1200 & 80 & 80 & 2,0 & 0,0 & 0,5 & 25,3 & 56,0 \\
\hline EZ_PG_N & gaz & 55 & 3000 & 2100 & 80 & 80 & 2,0 & 0,0 & 0,5 & 25,3 & 56,0 \\
\hline EZ_BIO_N & biomasa & 35 & 6200 & 160 & 160 & 2,0 & 2,0 & 12,6 & 190,0 & 144,1 & 0,0 \\
\hline EZ_JAD_N & en. nukl. & 100 & 18500 & 100 & 0 & 3,5 & 0,0 & 0 & 0 & 0 & 0 \\
\hline EZ_WOD_N & en. wod. & 100 & 12000 & 250 & 0 & 2,0 & 0,0 & 0 & 0 & 0 & 0 \\
\hline EZ_WIA_N & en. wiatr. & 100 & 6000 & 120 & 0 & 3,5 & 0,0 & 0 & 0 & 0 & 0 \\
\hline \multicolumn{12}{|c|}{ Elektrociepłownie zawodowe } \\
\hline EC_WK_I & w. kam. & 54.5 & 0 & 220 & 180 & 2,8 & 3,5 & 23,7 & 301,0 & 150,0 & 94,0 \\
\hline EC_WK_I_BIO & w. kam. & 55 & 0 & 220 & 180 & 2,8 & 3,5 & 9,7 & 58,7 & 60,5 & 68,2 \\
\hline EC_GAZ_I & gaz & 62.1 & 0 & 400 & 400 & 2,0 & 2,0 & 23,7 & 301,0 & 150,0 & 94,0 \\
\hline EC_WK_M_P & w. kam. & 57 & 600 & 200 & 180 & 2,8 & 3,5 & 19,0 & 240,9 & 125,1 & 86,4 \\
\hline EC_WK_M_T & w. kam. & 55 & 1200 & 200 & 180 & 2,8 & 3,5 & 23,7 & 30,1 & 50,0 & 94,0 \\
\hline
\end{tabular}




\begin{tabular}{|c|c|c|c|c|c|c|c|c|c|c|c|}
\hline EC_WK_M_F & w. kam. & 61 & 4100 & 200 & 180 & 2,8 & 3,5 & 23,7 & 250,0 & 150,0 & 84,6 \\
\hline EC_WK M B & w. kam. & 55 & 200 & 200 & 180 & 2,8 & 3,5 & 23,7 & 250,0 & 150,0 & 84,6 \\
\hline EC_WK_N & w. kam. & 56 & 8000 & 160 & 160 & 3,1 & 3,1 & 14,6 & 80,0 & 87,0 & 91,6 \\
\hline EC_TG_N & gaz & 62 & 3000 & 80 & 80 & 2,0 & 2,0 & 0,0 & 0,5 & 25,3 & 56,0 \\
\hline EC_PG_N & gaz & 55 & 3000 & 80 & 80 & 2,0 & 2,0 & 0,0 & 0,5 & 25,3 & 56,0 \\
\hline EC_OL_N & olej op. & 62 & 3000 & 80 & 80 & 2,0 & 2,0 & 19,7 & 67,0 & 46,2 & 72,8 \\
\hline \multicolumn{12}{|c|}{ Elektrociepłownie przemysłowe } \\
\hline EP_WK_I & w. kam. & 49 & 0 & 250 & 200 & 2,0 & 2,0 & 33,0 & 712,0 & 312,0 & 95,0 \\
\hline EP_WK_M_P & w. kam. & 50 & 600 & 250 & 200 & 2,0 & 2,0 & 33,0 & 712,0 & 312,0 & 95,0 \\
\hline EP_WK_M_T & w. kam. & 49 & 1200 & 250 & 200 & 2,0 & 2,0 & 26,4 & 569,7 & 254,7 & 87,2 \\
\hline EP_WK_M_B & w. kam. & 48 & 200 & 250 & 200 & 2,0 & 2,0 & 33,0 & 712,0 & 312,0 & 82,5 \\
\hline EP_GAZ_I & gaz & 49 & 0 & 100 & 100 & 2,0 & 2,0 & 0,0 & 0,5 & 25,3 & 56,0 \\
\hline EP_OP_I & olej op. & 49 & 0 & 100 & 100 & 2,0 & 2,0 & 19,7 & 67,0 & 46,2 & 72,8 \\
\hline EP_WK_N & w. kam. & 49 & 8000 & 100 & 100 & 2,0 & 2,0 & 14,6 & 230,0 & 87,2 & 85,2 \\
\hline EP_BIO_N & biomasa & 49 & 6200 & 100 & 100 & 2,0 & 2,0 & 12,6 & 190,0 & 144,1 & 0,0 \\
\hline EP_TG_N & gaz & 49 & 3000 & 100 & 100 & 2,0 & 2,0 & 0,0 & 0,5 & 25,3 & 56,0 \\
\hline EP_OL_N & olej op. & 49 & 3000 & 100 & 100 & 2,0 & 2,0 & 19,7 & 67,0 & 46,2 & 72,8 \\
\hline \multicolumn{12}{|c|}{ Ciepłownie zawodowe, przemysłowe i komunalne } \\
\hline CP_WK_I & w. kam. & 77.4 & 0 & 0,0 & 70 & 0,0 & 3,0 & 617,5 & 1015,7 & 371,2 & 95,0 \\
\hline CP_WK_M_P & w. kam. & 80 & 600 & 0,0 & 70 & 0,0 & 3,0 & 617,5 & 1015,7 & 371,2 & 95,0 \\
\hline CP_WK_M_T & w. kam. & 90 & 1200 & 0,0 & 70 & 0,0 & 3,0 & 494,0 & 812,7 & 302,7 & 87,2 \\
\hline $\mathrm{CP} O \mathrm{OL} \mathrm{I}$ & olej op. & 90 & 0 & 0 & 35 & 0.0 & 2.0 & 19,7 & 67,0 & 46,2 & 72,8 \\
\hline CP_GAZ_I & gaz & 90 & 0 & 0 & 35 & 0.0 & 2.0 & 0,0 & 0,5 & 25,3 & 56,0 \\
\hline CP_WK_N & w. kam. & 82 & 5900 & 0,0 & 70 & 0,0 & 3,0 & 14,6 & 230,0 & 87,2 & 85,2 \\
\hline CP_OL_N & olej op. & 90 & 3000 & 0,0 & 35 & 0,0 & 2,0 & 19,7 & 67,0 & 46,2 & 72,8 \\
\hline CP_GAZ_N & gaz & 90 & 3000 & 0,0 & 35 & 0,0 & 2,0 & 0,0 & 0,5 & 25,3 & 56,0 \\
\hline CP_BIO_N & biomasa & 80 & 4000 & 0,0 & 35 & 0,0 & 2,0 & 3,7 & 1,5 & 64,8 & 0,0 \\
\hline CP_GEO_N & geotermia & 100 & 3000 & 0,0 & 35 & 0,0 & 2,0 & 0,0 & 0,0 & 0,0 & 0,0 \\
\hline CP_SL_N & en. słon. & 100 & 10000 & 0,0 & 35 & 0,0 & 2,0 & 0,0 & 0,0 & 0,0 & 0,0 \\
\hline
\end{tabular}

* oznaczenia: WK - węgiel kamienny, WB - węgiel brunatny, WOD - wodne, WIA - wiatrowe, PGK - układy parowo-gazowe ze zgazowaniem węgla kamiennego, PGB - układy parowo-gazowe ze zgazowaniem węgla kamiennego, TG - turbiny gazowe, PG - układy parowo-gazowe na gaz ziemny, BIO - współspalanie biomasy i biogaz, JAD - jądrowe, OL - olej opałowy, GEO - geotermalne, SL - słoneczne, I - istniejące, M - modernizowane, $\mathrm{N}$ - nowe, $\mathrm{P}$ - modernizacja podstawowa, $\mathrm{T}$ - modernizacja podstawowa + turbina gazowa, $\mathrm{F}-$ kotły fluidalne, $\mathrm{B}-\mathrm{biomasa}_{\mathrm{S}} \mathrm{S}-\mathrm{sekwestracja} \mathrm{CO}{ }_{2}$

Źródło: opracowanie własne. 
W drugim scenariuszu wyznaczana jest optymalna struktura produkcji energii dla pełnej internalizacji kosztów zewnętrznych. Koszty zewnętrzne powodowane przez krajowe elektrownie, elektrociepłownie i ciepłownie przypisano - na podstawie własnych badań - do poszczególnych typów emitowanych zanieczyszczeń (11 tys. zł/Mg pyłu, 6 tys. zł/Mg NOx, 7 tys. zł/Mg SO2) [Kudełko 2009]. Zatem im większe współczynniki emisji technologii energetycznych, tym większe szkody powodowane emisją zanieczyszczeń. Scenariusz ten ma dwie wersje: w pierwszej „efektywnościowy” (1) - nie obowiązują żadne regulacje środowiskowe, a redukcja emisji zanieczyszczeń oraz wielkość produkcji energii pochodzącej z technologii odnawialnych są wynikiem optymalizacji. W ten sposób dokonywana jest weryfikacja obowiązujących przepisów w zakresie ochrony środowiska z punktu widzenia kryterium efektywności alokacyjnej. W wersji drugiej - „efektywnościowy” (2) dodatkowo wymuszono spełnienie dwóch ograniczeń dotyczących dopuszczalnych rocznych emisji zanieczyszczeń gzowych oraz limitów produkcji OZE. Miało to na celu sprawdzenie, w jakim stopniu kierunek polityki środowiskowej UE jest spójny $\mathrm{z}$ postulatem efektywności alokacyjnej realizowanym w wersji pierwszej.

\section{Wyniki symulacji}

W tabeli 2. przedstawiono wyniki symulacji komputerowych dla rozpatrywanych scenariuszy badawczych. Tabela zawiera łączną produkcję energii elektrycznej i ciepła w poszczególnych technologiach energetycznych, stąd wybór jednostki PJ jako wspólnej dla obu rodzajów energii. Zaczerniono te technologie, których poziom produkcji ulega zmianom.

W scenariuszu „bazowym” zmiany strukturalne obserwowane są w kilku obszarach związanych z wykorzystaniem poszczególnych technologii energetycznych. Po pierwsze, stosunkowo wysoka cena biomasy do pewnego stopnia ogranicza (lecz nie eliminuje) ten rodzaj dostosowań do narzuconych limitów OZE. Dodatkowo farmy wiatrowe umożliwiają wypełnienie limitów produkcji energii odnawialnej w bilansie produkcyjnym. Jako konkurencyjne pojawiają się nowe technologie energetyczne oparte na węglu kamiennym (np. wysokowydajne kotły energetyczne na parametry nadkrytyczne, układy parowo-gazowe ze zgazowaniem węgla czy wysokosprawne bloki spalające węgiel kamienny). Z powodu wysokich kosztów paliwowych technologie gazowe nie są rozwijane. Zakładana od roku 2025 możliwość budowy elektrowni jądrowej nie znajduje potwierdzenia w wynikach niniejszych symulacji. Mimo że jest to technologia bezemisyjna, jej koszty inwestycyjne są bez porównania wyższe niż ich alternatywy. W energetyce przemysłowej i lokalnej węgiel kamienny nadal powinien być paliwem podstawowym, choć konieczne będą modernizacje starych urządzeń czy budowa nowych zakładów. Technologie wykorzystujące gaz i źródła odnawialne, w tym biomasę i źródła geotermalne (na małą skalę w ciepłownictwie), mogą być konkurencją dla technologii węglowych. 
Tabela 2. Produkcja energii elektrycznej i ciepła w poszczególnych technologiach, PJ

\begin{tabular}{|l|r|r|r|r|r|r|r|r|r|}
\hline \multicolumn{1}{|c|}{ Technologia } & \multicolumn{2}{c|}{ scenariusz „,bazowy” } & \multicolumn{3}{c|}{$\begin{array}{c}\text { scenariusz } \\
\text {,efektywnościowy” (1) }\end{array}$} & \multicolumn{3}{c|}{ „efektywnościowy” (2) } \\
\hline & 2017 & 2020 & 2030 & 2017 & 2020 & 2030 & 2017 & 2020 & 2030 \\
\hline EZ_WK_I & 184 & 151 & 40 & 184 & 151 & 40 & 184 & 151 & 40 \\
\hline EZ_WK_I_BIO & 94 & 77 & 21 & 58 & 77 & 0 & 56 & 74 & 0 \\
\hline EZ_WK_M_P & 2 & 33 & 138 & 2 & 33 & 138 & 2 & 33 & 138 \\
\hline EZ_WB_I & 115 & 94 & 25 & 115 & 94 & 25 & 115 & 94 & 25 \\
\hline EZ_WB_I_BIO & 64 & 52 & 14 & 64 & 52 & 14 & 64 & 52 & 14 \\
\hline EZ_WB_M_P & 1 & 22 & 91 & 1 & 22 & 91 & 1 & 22 & 91 \\
\hline EZ_WOD_I & 10 & 8 & 2 & 10 & 8 & 2 & 10 & 8 & 2 \\
\hline EZ_WIA_I & 8 & 6 & 2 & 8 & 6 & 2 & 8 & 6 & 2 \\
\hline EZ_WK_N & 0 & 5 & 25 & 0 & 0 & 25 & 0 & 0 & 25 \\
\hline EZ_PGB_N & 11 & 53 & 157 & 41 & 53 & 164 & 41 & 53 & 164 \\
\hline EZ_WIA_N & 0 & 34 & 95 & 0 & 0 & 0 & 1 & 34 & 96 \\
\hline EZ_JAD_N & 0 & 0 & 0 & 0 & 0 & 25 & 0 & 0 & 0 \\
\hline EC_WK_I & 180 & 158 & 86 & 180 & 158 & 86 & 180 & 158 & 86 \\
\hline EC_WK_B_BIO & 33 & 29 & 16 & 33 & 29 & 16 & 33 & 29 & 16 \\
\hline EC_GAZ_I & 21 & 18 & 10 & 21 & 18 & 10 & 21 & 18 & 10 \\
\hline EC_WK_M_B & 2 & 23 & 95 & 2 & 23 & 95 & 2 & 23 & 95 \\
\hline EC_PG_N & 0 & 0 & 0 & 0 & 0 & 11 & 0 & 0 & 11 \\
\hline EP_WK_I & 63 & 57 & 38 & 63 & 57 & 38 & 63 & 57 & 38 \\
\hline EP_WK_M_P & 0 & 0 & 0 & 0 & 0 & 0 & 0 & 0 & 15 \\
\hline EP_WK_M_B & 1 & 6 & 25 & 0 & 0 & 0 & 0 & 0 & 0 \\
\hline EP_GAZ_I & 5 & 5 & 3 & 5 & 5 & 3 & 5 & 5 & 3 \\
\hline EP_OP_I & 62 & 56 & 38 & 62 & 56 & 38 & 62 & 56 & 38 \\
\hline EP_BIO_I & 32 & 29 & 20 & 32 & 29 & 20 & 32 & 29 & 20 \\
\hline CP_WK_I & 174 & 159 & 106 & 0 & 0 & 0 & 0 & 0 & 0 \\
\hline CP_WK_M_P & 2 & 17 & 70 & 0 & 0 & 0 & 0 & 0 & 0 \\
\hline CP_OL_N & 7 & 9 & 12 & 0 & 0 & 0 & 0 & 0 & 0 \\
\hline CP_BIO_N & 0 & 0 & 0 & 169 & 171 & 186 & 169 & 179 & 191 \\
\hline CP_GEO_N & 1 & 3 & 9 & 1 & 3 & 9 & 1 & 3 & 9 \\
\hline
\end{tabular}

Uwaga: w tabeli przedstawiono tylko te technologie, które produkują energię; pełna lista technologii znajduje się w tabeli 1.

Źródło: opracowanie własne.

Poważne zmiany zachodzą w scenariuszu „efektywnościowym”, uwzględniającym negatywne skutki związane $\mathrm{z}$ emisją zanieczyszczeń. W tabeli 2. zaznaczono technologie, w których produkcja energii ulega zmianom w porównaniu ze scenariuszem „bazowym”. Aby lepiej je zrozumieć, należy zaznaczyć, że w tym scenariuszu na skalę o wiele szerszą dokonywana jest redukcja emisji zanieczyszczeń metodami pierwotnymi - poprzez budowę zakładów odsiarczania spalin, instalację palników niskoemisyjnych czy katalityczną redukcję emisji. Decyzje te wynikają z porównania kosztów redukcji emisji ze współczynnikami kosztów zewnętrznych, które są od nich o wiele niższe. Zatem dokonywane zmiany strukturalne w energetyce zawodowej są niejako pochodną tych procesów i je uzupełniają. I tak nieznacznie maleje znaczenie współspalania biomasy, a w nieco większym stopniu stosowane są układy 
parowo-gazowe ze zgazowaniem węgla oraz na gaz ziemny. Ponadto niepotrzebne jest zwiększanie potencjału energetyki wiatrowej, natomiast opłacalna jest budowa elektrowni jądrowej (z uwagi na brak efektywnej metody redukcji emisji $\mathrm{CO}_{2}$ ). $\mathrm{W}$ energetyce przemysłowej zmiany są kosmetyczne (sztywne uwarunkowania technologiczne), natomiast w ciepłownictwie lokalnym wręcz ogromne. Tutaj bowiem nie jest możliwe zastosowanie pierwotnych metod redukcji emisji, konieczne są zmiany strukturalne. Model wybiera opcję całkowitego i natychmiastowego zamknięcia lokalnych kotłowni węglowych i zastąpienia ich kotłowniami zasilanymi biogazem i biomasą. Niska emisja pyłów z tych instalacji jest na tyle groźna dla ludzi, że zasadne jest podjęcie takiego wysiłku.

Scenariusz „efektywnościowy” (2) tylko nieznacznie różni się od wersji (1). Tutaj na maksymalną skalę rozwijana jest energetyka wiatrowa (tak jak w wariancie „bazowym”), co jest konsekwencją narzuconego wymogu produkcji ze źródeł odnawialnych. Z kolei budowa elektrowni jądrowej zacznie być opłacalna nieco później, bo od roku 2035. W energetyce przemysłowej i lokalnej nie zachodzą istotne różnice.

Realizacja scenariusza „efektywnościowego” w znacznym stopniu ogranicza emisję zanieczyszczeń gazowych pochodzących z energetyki zawodowej, przemysłowej i lokalnej (tab. 3). W przypadku emisji $\mathrm{SO}_{2}, \mathrm{NO}_{\mathrm{x}}$ i pyłów spadki sięgają kilkudziesięciu procent, a ich przyczyny zostały wcześniej omówione. Redukcja emisji $\mathrm{CO}_{2}$ jest o wiele mniejsza $\mathrm{i}$ wynosi kilkanaście procent, co wynika z braku pierwotnych metod redukcji1. Konsekwencją spadku emisji są podobne spadki kosztów zewnętrznych poszczególnych polutantów (tab. 3, rys. 1).

Tabela 3. Emisja zanieczyszczeń gazowych i koszty zewnętrzne w energetyce

\begin{tabular}{|c|c|c|c|c|c|c|c|c|c|}
\hline Wyszczególnienie & \multicolumn{3}{|c|}{ Scen. „bazowy” } & \multicolumn{3}{|c|}{$\begin{array}{l}\text { Scen. ,efektywnościo- } \\
\text { wy” (1) - zmiana [\%] }\end{array}$} & \multicolumn{3}{|c|}{$\begin{array}{l}\text { Scen. ,efektywnościo- } \\
\text { wy” (2) - zmiana [\%] }\end{array}$} \\
\hline Emisja, tys. $\mathrm{Mg}$ & 2017 & 2020 & 2030 & 2017 & 2020 & 2030 & 2017 & 2020 & 2030 \\
\hline $\mathrm{SO}_{2}$ & 633 & 614 & 553 & -46 & -51 & -83 & -46 & -52 & -82 \\
\hline NOX & 344 & 337 & 308 & -30 & -34 & -65 & -30 & -36 & -68 \\
\hline $\mathrm{CO}_{2}$ & 177866 & 178263 & 173208 & -13 & -10 & -7 & -13 & -14 & -15 \\
\hline PYL & 168 & 168 & 165 & -83 & -83 & -84 & -83 & -83 & -85 \\
\hline $\begin{array}{l}\text { Koszty zewnętrzne, } \\
\text { mln zł }\end{array}$ & 2017 & 2020 & 2030 & 2017 & 2020 & 2030 & 2017 & 2020 & 2030 \\
\hline $\mathrm{SO}_{2}$ & 17711 & 17191 & 15471 & -46 & -51 & -83 & -46 & -52 & -82 \\
\hline NOX & 7855 & 7684 & 7017 & -30 & -34 & -65 & -30 & -36 & -68 \\
\hline $\mathrm{CO}_{2}$ & 13518 & 13548 & 13164 & -13 & -10 & -7 & -13 & -14 & -15 \\
\hline PYL & 7408 & 7377 & 7242 & -83 & -83 & -84 & -83 & -83 & -85 \\
\hline
\end{tabular}

Źródło: opracowanie własne.

$1 \mathrm{~W}$ istocie w modelu zaimplementowana jest opcja wykorzystania sekwestracji $\mathrm{CO}_{2}$, jednak jej koszt jest bez porównania wyższy niż koszt zewnętrzny powodowany emisją tego gazu, nie jest więc efektywna. 


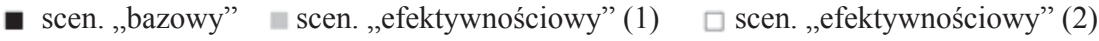

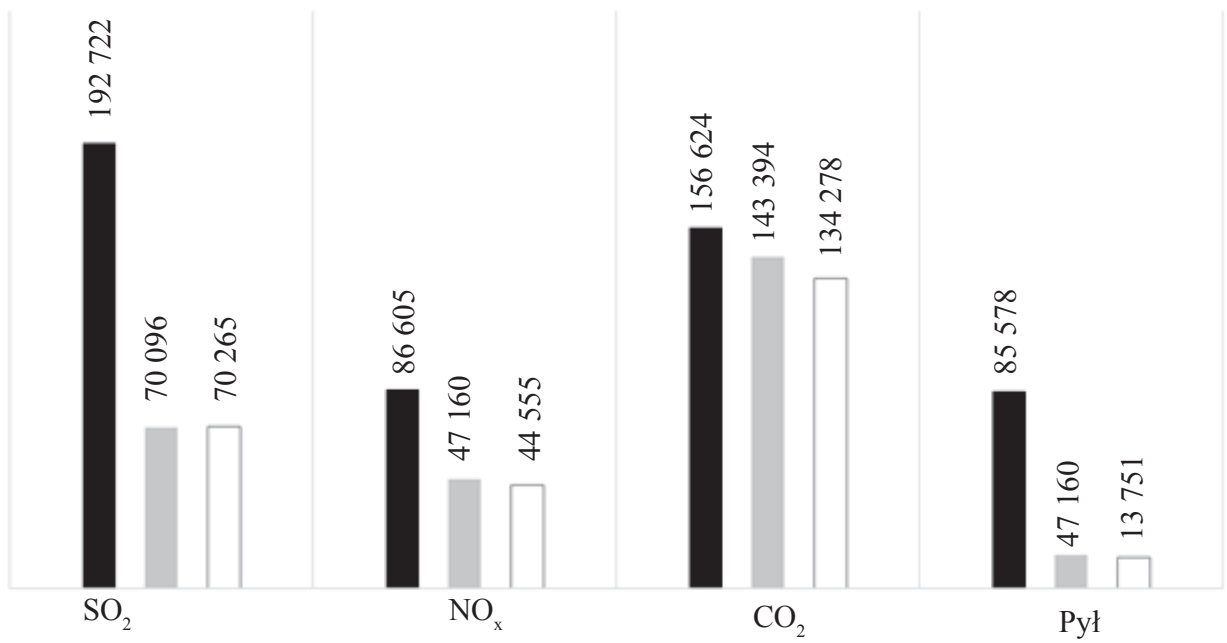

Rys. 1. Zdyskontowane koszty zewnętrzne poszczególnych polutantów [mln zł]

Źródło: opracowanie własne.

Decydującym kryterium porównawczym rozpatrywanych scenariuszy rozwojowych są koszty społeczne ich realizacji, będące sumą zdyskontowanych kosztów systemowych (czyli sumy kosztów inwestycyjnych, paliwowych, zmiennych i stałych technologii energetycznych, kosztów redukcji emisji i kosztów zakupu uprawnień zbywalnych) oraz kosztów zewnętrznych związanych z emisją zanieczyszczeń gazowych (rys. 2). Scenariusz „efektywnościowy” jest co prawda „droższy” od „bazowego" w sensie ponoszonych kosztów systemowych (produkcji) - 638 mld zł w stosunku do 623 mld zł, jednak generuje o wiele niższe koszty zewnętrzne (275 zamiast $521 \mathrm{mld}$ zł). Sumaryczny poziom kosztów społecznych w scenariuszu „efektywnym” jest o $20 \%$ niższy niż w scenariuszu „bazowym”. Źródłem niższych kosztów zewnętrznych są redukcje emisji odpowiednio $\mathrm{SO}_{2}$, pyłów, $\mathrm{NO}_{x}$ i $\mathrm{CO}_{2}$. Porównanie wyników dwóch wariantów „efektywnościowych” wskazuje, że wariant (2) jest tylko nieznanie droższy niż (1), o $0,3 \%$, co potwierdza słuszność realizacji polityki UE w zakresie większego wykorzystania odnawialnych źródeł energii. 
800000

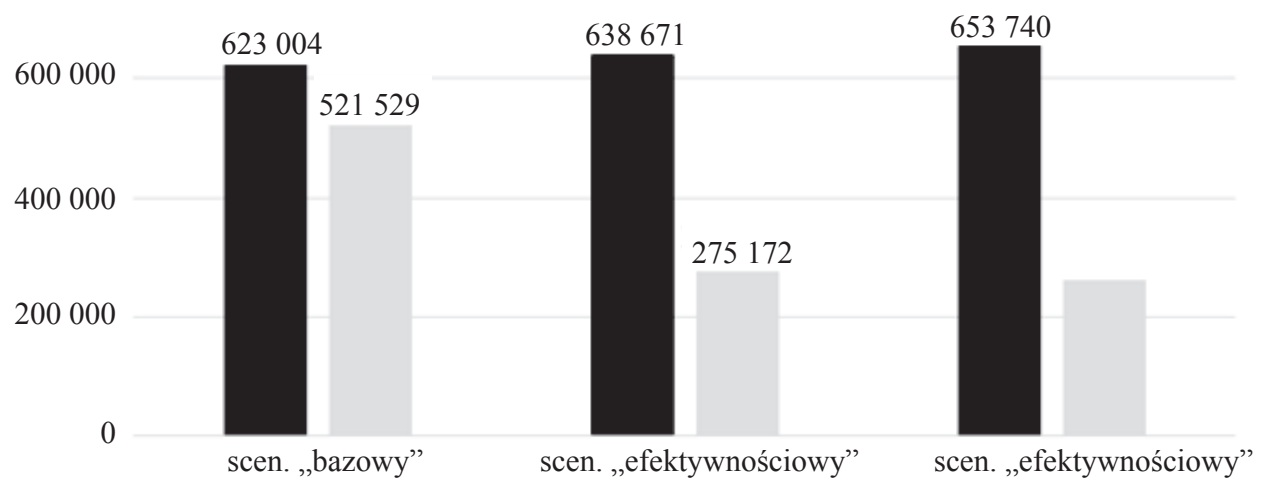

(1)

(2)

Koszty systemowe

Koszty zewnętrzne

Rys. 2. Zdyskontowane koszty systemowe i zewnętrzne [mln zł]

Źródło: opracowanie własne.

\section{Zakończenie}

Jednakowe traktowanie prywatnych kosztów przedsiębiorstw energetycznych i kosztów zewnętrznych powodowanych emisją zanieczyszczeń gazowych - a nie ma ekonomicznego uzasadnienia, by tego nie czynić - ma decydujące znaczenie przy podejmowaniu decyzji inwestycyjnych (alokacyjnych) w sektorze energetycznym. W porównaniu z tradycyjnym modelem rozwojowym zakres działań proekologicznych w modelu „efektywnościowym” powinien być znacznie szerszy. Po pierwsze, poziom redukcji emisji u źródeł winien być znacznie większy. Pokrywa się to z obecną polityką UE, zmierzającą do obowiązku realizacji nowych inwestycji spełniających wymóg BAT (Best Available Technology). Po drugie, efektywnym sposobem redukcji emisji $\mathrm{CO}_{2}$ jest energetyka jądrowa. Po trzecie, zjawisko niskiej emisji odpowiedzialnej za liczne choroby układu oddechowego i krążenia powinno być natychmiast wyeliminowane poprzez zamknięcie starych ciepłowni opalanych węglem kamiennym. W związku z tym należy mieć nadzieję, że polityka środowiskowa UE, która dostrzega i uwzględnia te procesy, znajdzie większe zrozumienie wśród decydentów gospodarczych. Związany z tym nieunikniony wzrost cen energii i tak jest rozwiązaniem ekonomicznie lepszym niż dotychczasowy kierunek rozwoju energetyki. 


\section{Literatura}

Air quality in Europe - 2017 report, 2017, EEA Report, no 13.

Brook A., Kendrick D., Meeraus A., 1992, GAMS Users' Guide, The Scientific Press, San Francisco.

Fahlén E., Ahlgren O., 2010, Accounting for external costs in a study of a Swedish district-heating system - An assessment of environmental policies, Energy Policy, vol. 38, issue 9, Elsevier Science.

Georgakellos D., 2012, Climate change external cost appraisal of electricity generation systems from a life cycle perspective: the case of Greece, Journal of Cleaner Production, vol. 32, Elsevier Science.

Jankowski B., 2010, Ocena skutków zaostrzenia unijnej polityki klimatycznej dla Polski, ze szczególnym uwzględnieniem sektora elektroenergetycznego do roku 2050, Elektroenergetyka: Współczesność i Rozwój, nr 4 (6).

Klaassen G., Riahi K., 2007, Internalizing externalities of electricity generation: An analysis with MESSAGE-MACRO, vol. 35, issue 2, Elsevier Science.

Krzemień J., Jaskólski M., Jędrysik E., 2013, Badania modelowe rozwoju krajowego systemu energetycznego przy użyciu narzędzia optymalizacyjnego MARKAL, Energetyka, nr 5.

Kudełko M., 2003, Efektywna alokacja zasobów w krajowym systemie energetycznym, Studia, Rozprawy, Monografie, nr 121, Wydawnictwo IGSMiE PAN, Kraków.

Kudełko M., 2006, Internalisation of external costs in the Polish power generation sector: A partial equilibrium model, Energy Policy, vol. 34, issue 18, Elsevier Science.

Kudełko M., 2009, External costs of Power Plants - Results of the NEEDS Project, Rynek Energii, nr 4 (84), Lublin.

Kudełko M., Suwała W., Kamiński J., 2007, Koszty zewnętrzne w energetyce - zastosowanie w badaniach modelowych, Studia, Rozprawy, Monografie, nr 139, Wydawnictwo IGSMiE PAN, Kraków.

Kudełko M., Suwała W., Kamiński J. Kszyński P., 2011, Modelowanie rynków energii dla różnych systemów dystrybucji uprawnień do emisji dwutlenku węgla, Studia, Rozprawy, Monografie, nr 173, Wydawnictwo IGSMiE PAN, Kraków.

Kudełko M., Suwała W., Kamiński J. Kszyński P., 2012, Handel uprawnieniami do emisji dwutlenku węgla w Unii Europejskiej, Studia, Rozprawy, Monografie, nr 178, Wydawnictwo IGSMiE PAN, Kraków.

Kudełko M., Wolak J., Czyż M., Kołodziej-Hajdo M., Marcinkowska E., Posłuszny K., Szydło S., Skrzyński P., Gdowska K., 2013, Wybrane problemy metodyki badań rozwoju przedsiębiorstw polskich po transformacji do gospodarki rynkowej, Wydawnictwa AGH, Kraków.

Model optymalnego miksu energetycznego dla Polski do roku 2060, 2015, Departament Analiz Strategicznych, Kancelaria Prezesa Rady Ministrów, Warszawa.

Orzechowska M., Malec M., Kaszyński P., 2015, Krótkoterminowa analiza zmian struktury wytwórczej polskiego sektora elektroenergetycznego przy użyciu uslugi ModWEEL, Zeszyty Naukowe IGSMiE PAN, nr 89.

Rafaj P., Kypreos S., 2007, Internalisation of external cost in the power generation sector: Analysis with Global Multi-regional MARKAL model, Energy Policy, vol. 35, issue 2, Elsevier Science.

Ścieżki dekarbonizacji. Model miksu elektroenergetycznego do roku 2035 wraz z analiza potencjalnych problemów bilansowania KSE z generacja wiatrowa, 2018, Krajowy Instytut Energetyki Rozproszonej, Warszawa.

Weinzettela J., Havránek M., Ščasný M., 2012, A consumption-based indicator of the external costs of electricity, Ecological Indicators, vol. 17, Elsevier Science.

Wierzbowski M., Olek B., Łyżwa W., 2014, Optymalizacja krajowego miksu energetycznego w kontekście polityki energetycznej, Rynek Energii, $\mathrm{nr} 5$.

Zhang Q., Weili T., Yumei W., Yingxu C., 2007, External costs from electricity generation of China up to 2030 in energy and abatement scenarios, Energy Policy, vol. 35, issue 8, Elsevier Science.

Zvingilaite Z., 2011, Human health-related externalities in energy system modelling the case of the Danish heat and power sector, Applied Energy, vol. 88, issue 2, Elsevier Science. 